\title{
THE INFLUENCE OF EFFICIENCY ESTIMATES ON THE FINANCIAL RATIOS OF SOUTH AFRICAN LISTED BANKS
}

\author{
Merwe Oberholzer* \\ North-West University \\ Merwe.Oberholzer@nwu.ac.za \\ Gert van der Westhuizen\# \\ North-West University \\ gvdwesthuizen@absamail.co.za
}

November 2009

\begin{abstract}
The purpose of this study is to determine the relationship between bank efficiency estimates, measured by Data Envelopment Analysis (DEA), and bank performance, measured by the financial ratios included in the Du Pont analysis. Annual financial statement reports were used to calculate the performance of listed banks on the JSE Limited over a ten-year period. This study is the first to use two unique DEA models: one focuses on the efficiency of the finance and investment activity, and the other on the efficiency of the operating activity of banks. The study found that the majority of significant relationships between efficiency estimates and financial ratios are negatively correlated. Further research is needed to explain this phenomenon. The practical implication of this study is that it indicates that an improvement in the DEA efficiency estimates will not necessarily result in better financial ratios. Therefore, both measurements should be used to evaluate different aspects of performance in order to stay competitive.
\end{abstract}

\section{Keywords:}

Data Envelopment Analysis, technical efficiency, allocative efficiency, cost efficiency, financial ratio analysis

\footnotetext{
* Prof Merwe Oberholzer is a senior academic from the Research Unit for Economic and Management Sciences, Faculty of Economic and Management Sciences, North-West University (Potchefstroom Campus), South Africa

\# Prof Gert van der Westhuizen is a senior academic from the Unit for Business Mathematics and Informatics, Faculty of Economic Sciences and Information Technology, Vaal Triangle Campus of North-West University (Vanderbijlpark Campus), South Africa
} 


\section{INTRODUCTION}

This study focuses on the phenomenon that since 1994 a large number of foreign banks have become established in South Africa and many of them have taken over some of the market share of the local banks (Cronje, 2007). This has forced the local banks to improve their performance in order to remain competitive. Therefore, performance measures are important to determine how well a bank is doing as well as to predict future performances.

Financial ratios can be used as a tool for performance measurement. Different financial ratios provide different answers in relation to organisational performance. A firm or a sub-unit might be highly rated by one of these ratios, while another ratio shows the opposite (Horngren, Datar, Foster, Rajan \& Ittner, 2009). The reasons for these contradictions are that the ratios focus on different aspects, have different advantages and have different limitations (Correia, LangfieldSmith, Thorne \& Hilton, 2008).

Another tool to measure performance is efficiency estimates. The two most widely used quantitative techniques for measuring relative productivity (or relative efficiency) are Stochastic Frontier Analysis and Data Envelopment Analysis (DEA) (Coelli, Rao, O'Donnel \& Battese, 2005). DEA is used in this study as an efficiency measurement because it lends itself more readily to the analysis of multiple-output firms.

The purpose of the study is to determine the relationship between bank performance, estimated by DEA, and bank financial ratio performance, determined by the Du Pont analysis. The South African listed banks will be investigated. Ratio analysis examines a bank's financial position, takes risks into account and has a view to forecast a bank's future prospects (Correia, Flynn, Uliana \& Wormald, 2007). DEA, on the other hand, computes the relative efficiency of a comparative ratio of outputs to inputs for each bank (Avkiran, 1999; Ray, 2004). Therefore, the results of the study will indicate to what extent a change in the efficiency of banks will result in a change in the financial ratios of the banks investigated.

\section{LITERATURE REVIEW AND STATEMENT OF THE PROBLEM}

There are many different financial ratios, since any two values in the financial statements can be a ratio. In this study, the ratios in the Du Pont analysis have been chosen. Correia, et al. (2007) state that the strength of this analysis is the fact that three broad categories of a firm are explained, namely those associated with income, investment and capital structure.

Apart from a number of limitations of ratio analysis (Correia, et al., 2007), another weakness is that a firm may appear to be performing well, even if it is poorly managed in some of these dimensions, as long as it compensates by performing well in other dimensions (Sherman \& Gold, 1985). A further weakness of ratio analysis is that the literature cannot agree upon the relative importance of the different ratios and it is only appropriate if firms use a single input or produce a single output (Chen, 2002). Therefore, since no single financial ratio on its own provides an adequate indication of a bank's efficiency, DEA can be helpful in this regard to indicate " $a$ rounded judgement on firms' efficiency." (Halkos \& Dimitrios, 2004:205.)

Some previous studies use DEA efficiency estimates and compare them with financial ratios, e.g. Oberholzer and Van der Westhuizen (2004) and Yeh (1996), who found that DEA efficiency estimates are tools to compensate for the weaknesses of financial ratios. Halkos and Dimitrios 
(2004) also found that DEA could be used as an alternative, or complement, to financial ratio analysis. Hassan Al-Tamimi and Lootah (2007) found that financial ratios fail to consider multiple outputs that are provided by multiple inputs.

DEA has previously been used to study the performance of banks at both the firm and corporate level (cf. Halkos \& Dimitrios, 2004; Drake, 2001; Devaney \& Weber, 2000; Berger \& Humphrey, 1997; Cronje, 2002), and at the branch level (cf. Sherman \& Ladino, 1995; Sherman \& Gold, 1985; 0 'Donnell \& Van der Westhuizen, 2002; Van der Westhuizen \& Oberholzer, 2003; Oberholzer \& Van der Westhuizen, 2004; Van der Westhuizen, 2008).

The above-mentioned DEA studies used different variables in their models. These variables include a combination of income statement data, balance sheet data and other non-financial data. The major challenge is to measure the efficiency by using sensible combinations of variables in a DEA model. However, in spite of the widespread adoption of DEA in banks as an efficiency measurement, there has been no empirical linkage between the efficiency of banks' operating activity and financial ratios, and the efficiency of banks' finance/investment activity and financial ratios. This study is thus the first to measure DEA efficiency by means of two separate DEA models, where the first model focuses on the efficiency of banks' operating activity, as measured by the income statement (Dempsey \& Pieters, 2005), while the second model focuses on the efficiency of banks' finance/investment activity, as measured by the balance sheet (Dempsey \& Pieters, 2005:124). (For ease of reference, the two DEA models will be indicated as income statement-based and balance sheet-based. Section 7 explains the two DEA models.)

The problem of the study can be summarised by the following question: What is the influence of bank efficiency, as estimated by the two DEA models, on bank performance, as measured by financial ratios?

\section{OBJECTIVE AND RELEVANCE OF THE STUDY}

In response to the problem identified in the previous section, the three objectives of this paper are as follows:

- To measure bank performance by using DEA models that are firstly income statementbased, and secondly balance sheet-based, and to estimate, according to both models, the technical, allocative and cost efficiency of a number of banks listed on the JSE Limited.

- To measure the performance of the above-mentioned banks by using financial ratio analysis, i.e. the ratios included in the Du Pont analysis.

- To determine the relationship between the DEA estimates, according to the two models, and the financial ratio analysis.

\section{HYPOTHESIS}

With reference to the objective of the study, the DEA models and financial ratio analysis will be helpful in testing the following null-hypotheses for each bank under review as well as all the banks together: 
- Null-hypothesis one:

$\mathrm{H}_{0}$ : There is no significant relationship between the efficiencies of the income statementbased DEA model and the financial ratio analysis.

- Null-hypothesis two:

$\mathrm{H}_{0}$ : There is no significant relationship between the efficiencies of the balance sheet-based $D E A$ model and the financial ratio analysis.

\section{DEA METHODOLOGY}

$D E A$ is a non-parametric linear programming technique that measures the relative efficiency of a comparative ratio of outputs to inputs for each decision-making unit, such as a firm (Ray, 2004; Avkiran, 1999). A firm is efficient "if it cannot produce more output without a corresponding relative increase in inputs, or if it cannot reduce its inputs without a corresponding relative decrease in outputs" (Thomas \& Tripe, 2007:4). The traditional measurement of efficiency (or productivity) assumes only a single output divided by a single input (Cronje, 2002; Horngren, et al., 2009). The main advantage of using DEA as a relative efficiency measure is that it accommodates multiple inputs, multiple outputs and other factors in a single model (Halkos \& Dimitrios, 2004). The main usefulness is its ability to identify inefficient firms, to generate potential improvement for them and to indicate efficient firms that should be used as a benchmark by inefficient ones (Avkiran, 1999).

DEA involves the use of linear programming methods to construct a non-parametric piece-wise surface (or frontier) over the data. Efficiency measures are then calculated relative to this surface (Coelli, et al., 2005). DEA can be used to estimate four main types of efficiency, namely technical, allocative, cost and scale efficiency. In practice, the measurement of these efficiencies involves the estimation of production frontiers. DEA effectively estimates the frontier by finding a set of linear segments that envelops the observed data.

For example, assuming that the observed data comprises two-input, single-output Firms $M, R$ and $A$, the DEA estimate of the production frontier will be the piecewise linear surface VMRV' as depicted in FIGURE 1. It is important to note that MV and RV' are parallel to the respective axes. A firm producing on this part of the frontier does not represent an efficient point, because the use of the respective inputs can be reduced without any reduction in output (Coelli, et al., 2005).

A firm is said to be technically efficient if it produces a given set of outputs using the smallest possible number of inputs. Allocative efficiency reflects the ability of a firm to use the inputs in optimal proportions, given their respective prices. A firm is cost efficient if it is both technically and allocatively efficient (Avkiran, 1999; Oberholzer \& Van der Westhuizen, 2009). The firm is said to be scale efficient if it operates on a scale that maximises productivity (Avkiran, 1999). Measuring scale and technical efficiency using DEA requires data on output and input quantities. Measuring allocative and cost efficiency also requires data on input prices. 


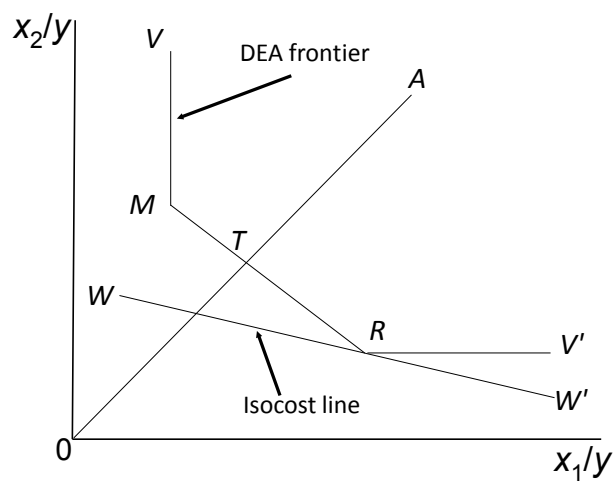

\section{FIGURE 1: Two-input single-output DEA frontier}

Source: Coelli, et al., 2005:52

Charnes, Cooper and Rhodes (1978) developed DEA as a linear programming technique to evaluate the efficiency of public sector non-profit organisations. According to Molyneux, et al. (1996:198), Sherman and Gold (1985) were the first to apply DEA to banking. The original model proposed by Charnes, et al. (1978) and adopted by Sherman and Gold (1985) is formulated as follows:

\section{Objective function}

$$
\max E_{o}=\frac{\sum_{i=1}^{k} u_{i} \psi_{i o}}{\sum_{j=1}^{m} v_{j} \chi_{j o}}, \rightarrow\left(\text { i.e maximise } \frac{\text { output index }}{\text { input index }}\right)
$$

where

$o=$ the branch being assessed from the set of $r=1,2, \ldots, n$ bank branches;

$k=$ the number of outputs at the branches;

$m$ = the number of inputs at the branches;

$\psi=$ observed output $i$ at branch $r$;

$\chi_{j r}=$ observed input $j$ at branch $r$.

Constraints

$$
\begin{gathered}
\frac{\sum_{j=1}^{m} u_{i} \psi_{i r}}{\sum_{j=1}^{m} v_{j} \chi_{j r}} \leq 1 \text { for all } r=1, \ldots, n \text { (boundary constraints) } \\
u_{i}, v_{j} \geq 0, \text { for all } i=1, \ldots, k \text { and } j=1, \ldots, m \text { (non-negativity constraints) }
\end{gathered}
$$

The above analysis is performed repetitively, with each bank branch in the objective function, producing efficiency ratings for each of the " $n$ " branches. The solution sought is the set of $\left(u_{i}, v_{i}\right)$ values that maximises the efficiency ratio $\varepsilon_{0}$ of the bank branch being rated, without resulting in 
an output/input ratio 1 when applied to each of the other branches in the dataset. For a more detailed discussion on the DEA methodology, see Coelli, et al. (2005), Cronje (2002) and Avkiran (1999).

\section{DATA SOURCES AND GENERAL METHODOLOGY}

Financial statement data at year-end from 1998 to 2007 was obtained from the McGregor database. Eight banks are/were listed on the JSE Limited (Sake-Rapport, 2009:6). Only five of the banks are included in the study. They are ABSA, Nedcor, First National Bank, Standard Bank, and Mercantile Bank. The banks that were excluded are Saambou and Rand Holdings BM, which only have data up to 2005 and 2003, respectively, and Capitec, which has only been operational since 2002.

In order to determine the DEA efficiencies, specific income statement and balance sheet data was extracted from the database. In total, 50 data points are available (five banks $x 10$ periods) to determine a bank's annual efficiency, relative to the other banks and relative to all the periods as explained in the DEA methodology. This is sufficient according to Avkiran (1999), who states that the sample size should be three times as large as the sum of the chosen variables in the DEA models. Each of the models defined uses only two input and two output variables (see Section 7).

Specific income statement and balance sheet data was also extracted from the database to determine the annual financial ratios of each bank (see Section 8). The rank order correlation of Spearman can be used to determine the relationship between the DEA efficiency estimates and the financial ratios. Rank order correlation is a non-parametric technique for qualifying the relationship between two variables. Non-parametric means that the correlation statistics are not affected by the type of mathematical relationship between variables, unlike the least square regression analysis, which requires the relationship to be linear (Vose, 1996:33). The rank order correlation coefficient is a more general measure of any kind of monotonic relationship between $x$ and $y$. This measure is based on ranks and is therefore not as sensitive to outliers (Millard \& Neerchal, 2001:534). At least ten observations are required to determine the correlation between two variables (Sekaran, 2006; Hanke, Wichern \& Reitsch, 2001). Since annual data from 1998 to 2007 is used, ten observations are available for each of the five banks. The study will further be extended to test the null-hypotheses. Significance levels of $1 \%, 5 \%$ and $10 \%$ will be used.

\section{DEA MODELS}

Two main approaches to define inputs and outputs in banking are used, namely the intermediation and the production approach. According to Berger and Humphrey (1997), under the production approach, banks produce accounts of various sizes by processing deposits and loans, incurring capital and labour costs. Under the intermediation approach, banks intermediate deposited and purchased funds into loans and other assets. Favero and Papi (1995) identify another three approaches to the input and output specifications, which are

(i) the asset approach,

(ii) the user-cost approach, and 
(iii) the value-added approach.

In this paper, a combination of approaches was used. Stavarek (2002) used financial capital as an input with a number of other inputs. Fixed assets or physical capital was used as an input by various authors, inter alia, Wheelock and Wilson (1995), Favero and Papi (1995), and Elyasiani and Mehdian (1992). To some extent the approach used by Rangan, Grabowski, Aly and Pasurka (1988) is adopted. The main reason for using this approach in Model 2 is that only balance sheet data was used in the case of outputs. Loans and deposits were also used as outputs by, inter alia, Aly, Grabowski, Pasurka and Rangan (1990), and Berger and Humphrey (1991). Financial capital and fixed assets were used in various combinations as inputs by Rangan, et al. (1988), Berger and Humphrey (1991), Aly, et al. (1990), and Favero and Papi (1995). In the case of Model 1 , only income statement data was used for the outputs and this, to some extent, corresponds with the outputs used by Charnes, Cooper and Haung (1990) and Chen (1998).

The following models were specified:

\section{Model 1 (Income statement-based)}

Outputs: $\quad y_{1}=$ Rand value of interest income

$\mathrm{y}_{2}=$ Rand value of non-interest income

Inputs: $\quad x_{1}=$ Rand value of deposits

$x_{2}=$ Rand value of staff and operating costs

Input prices: $\quad w_{1}=($ Rand volume of interest expenses $) / x_{1}$

$\mathrm{W}_{2}=$ Production price index (Index by P0142.1 by Statistics South Africa)

\section{Model 2 (Balance sheet-based)}

Outputs: $\quad y_{1}=$ Rand value deposits

$y_{2}=$ Rand value of loans

Inputs: $\quad x_{1}=$ Rand value of financial capital

$x_{2}=$ Rand value of fixed assets

Input prices: $\quad w_{1}=$ Production price index (Index by P0142.1 by Statistics South Africa)

$\mathrm{w}_{2}=($ Rand value of depreciation $) / \mathrm{x}_{2}$

The inputs and outputs in Model 1 , which focus on the efficiency of the operational activity, are not solely taken from the income statement. The input, Rand value of deposits, is a balance sheet item, but the input price, Rand volume of interest expenses, is an income statement item. If the income statement item, Rand volume of interest expenses, was used as the input (for example the model used by Hassan Al-Tamimi and Lootah (2007)), then deposits would have been the input price, which does not make any sense. All the inputs and outputs in Model 2, which focus on the efficiency of the finance/investment activity, are balance sheet items. Note that the input price of fixed assets is the depreciation charge that is taken from the income statement.

International Accounting Standards (IAS 30:§10) (IASB, 200) require that banks should report specific amounts, e.g. interest income, interest expenses, dividend income, etc. The interest 
income, deposits and loans used in the models are the amounts that are based on banking operations. For example, investment income does not form part of the interest income, and investments do not form part of loans.

\section{FINANCIAL RATIOS}

As mentioned, the components of the Du Pont analysis are used as the financial ratios in this study. This analysis indicates how return on equity (ROE) is affected by income/assets, the net profit margin (PM) and leverage (assets/equity) (Brigham \& Ehrhardt, 2005). FIGURE 2, taken from Correia, et al. (2007), is a simple but very informative explanation of the Du Pont analysis. See also Brigham and Ehrhardt (2005) and Horngren, et al. (2009) for similar expositions.

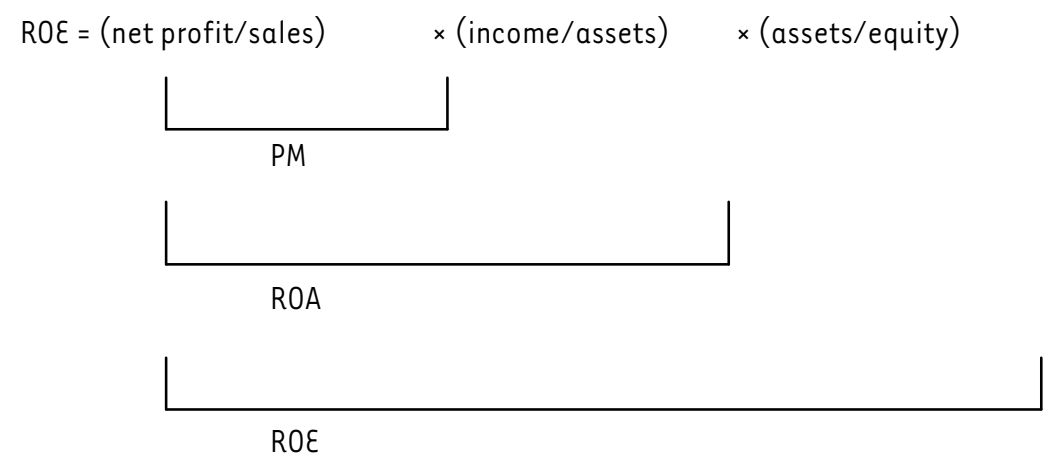

\section{FIGURE 2: Du Pont Analysis}

Source: Correia, et al., 2007:5-21

\section{THE CONCEPTUAL FRAMEWORK}

DEA is a measurement of efficiency. This study focuses on three efficiency estimates, namely technical, allocative and cost efficiency. Technical efficiency addresses the question by how much output quantities produced can be proportionally increased without changing the input quantities. Allocative efficiency addresses the question of how much the proportion of output quantities can be changed merely by altering the mix of inputs. The cost efficiency is an aggregation of both the technical and allocative efficiency and addresses the question of how much output quantities produced can be proportionally increased by using the minimum input quantities in an optimal mix.

The financial ratios PM, ROA and ROE are profitability performance measures. Income to assets is a performance ratio to indicate the efficiency in utilising assets to generate income. The expectation is that there is a positive co-variance between these four ratios and the DEA efficiency estimates, because they all measure performance of outputs relative to inputs. The asset-to-equity ratio is a measure with regard to capital structure compilation and does not measure an output relative to an input. Therefore, it is uncertain what its co-variance relation (if any) will be with the efficiency estimates. 
The research question - what is the influence of the efficiency of a bank's operations on its performance as measured by the use of financial ratios? - can now be refined, since all the variables in the DEA models and the financial ratios are indicated (cost efficiency is a function of technical and allocative efficiency, and will therefore not be discussed).

- Does the relative technical efficiency (input-output ratio of deposits and staff and operating costs to interest and non-interest income) of a bank influence its profitability, its efficiency in utilising assets to generate income and its capital structure?

- Does the relative allocative efficiency (input-mix ratio of deposits and staff and operating costs to generate interest income and non-interest income) of a bank influence its profitability, its efficiency in utilising assets to generate income and its capital structure?

- Does the relative technical efficiency (input-output ratio of fixed assets and financial capital to deposits and loans) of a bank influence its profitability, its efficiency in utilising assets to generate income and its capital structure?

- Does the relative allocative efficiency (input-mix ratio of financial capital and fixed assets to generate deposits and loans) of a bank influence its profitability, its efficiency in utilising assets to generate income and its capital structure?

\section{EMPIRICAL RESULTS}

\subsection{DEA results}

The software package DEAP Version 2.1 by Coelli (1996) is purpose-built to solve the DEA problem and has been used in this paper to generate estimates of technical, allocative and cost efficiency for each observation in the dataset (i.e. for each bank in each year).

TABLE 1 presents the necessary results of the DEA efficiency estimates. Bank 3 is, according to Model 1 , on average the most technically efficient (TE) with an average estimate of $93.5 \%$, which means that the bank can increase its output by $6.5 \%$ without increasing its input. Bank 1 is, according to Model 2, the most technically efficient, with an estimate of $91.8 \%$, which means it can increase its output by $8.2 \%$ without increasing its input. Bank 4 and Bank 2 are the most allocative efficient $(A \varepsilon)$ banks, according to Model 1 and Model 2, respectively. The average estimates are $99.7 \%$ and $99.9 \%$ respectively, which means Bank 4 can increase its output by 0.3 $\%$, and Bank 2 can increase its output by $0.1 \%$, just by altering their input mixes. Technical and allocative efficiency combined provide cost efficiency $(C \varepsilon)$. Bank 3 is, according to Model 1 , the most cost efficient, while Bank 1 is the most cost efficient according to Model 2, with average estimates of $91.3 \%$ and $90.4 \%$, respectively.

The technical efficiency of all the banks, except Bank 1, is higher in Model 1 than it is in Model 2. The overall average technical efficiency estimate for Model 1 ( $89.5 \%)$ is also higher than the estimate of Model $2(79.0 \%)$. Allocative efficiency, on the other hand, has mixed results with regard to the two models. The difference between the allocative efficiency in Model 1 and Model 2 is marginal for Bank 1, higher for Banks 2, 4 and 5 in Model 2, and higher for Bank 3 in Model 1. The overall averages are misleading with regard to allocative efficiency, since the distortion of the estimate of Bank 3 is extremely low for Model 2.

Another distortion problem that is experienced in TABLE 1 is that in Model 1, 27 out of 50 allocative efficiency estimates are the maximum of $100 \%$. That means that the ranking is from 1 
to 23 , and 27 estimates are together in $24^{\text {th }}$ position in the rank order. A similar problem exists in Model 2 , where 26 out of 50 allocative efficiency estimates are $100 \%$.

TABLE 1: Annual results from 1998 to 2007 per bank $(n=10)$ and in total $(n=50)$ of financial ratios analysis, DEA Model 1 and Model 2

\begin{tabular}{|c|c|c|c|c|c|c|c|c|c|c|c|}
\hline \multirow{3}{*}{ BANK } & \multirow{2}{*}{\multicolumn{5}{|c|}{ FINANCIAL RATIO ANALYSIS RESULTS }} & \multicolumn{6}{|c|}{ DEA RESULTS } \\
\hline & & & & & & \multicolumn{3}{|c|}{ Model 1} & \multicolumn{3}{|c|}{ Model 2} \\
\hline & PM & $\begin{array}{l}\text { Income/ } \\
\text { Assets }\end{array}$ & ROA & $\begin{array}{l}\text { Asset/ } \\
\text { Equity }\end{array}$ & ROE & Тह & $A \varepsilon$ & CE & $\mathrm{T \varepsilon}$ & AE & CE \\
\hline \multirow[t]{10}{*}{1} & 0.147 & 0.105 & 0.016 & 15.007 & 0.233 & 0.917 & 0.942 & 0.864 & 0.864 & 1.000 & 0.864 \\
\hline & 0.163 & 0.101 & 0.016 & 14.166 & 0.232 & 1.000 & 1.000 & 1.000 & 0.847 & 1.000 & 0.847 \\
\hline & 0.179 & 0.162 & 0.029 & 15.603 & 0.452 & 0.818 & 0.933 & 0.763 & 0.894 & 1.000 & 0.894 \\
\hline & 0.125 & 0.117 & 0.015 & 15.331 & 0.225 & 0.746 & 0.966 & 0.721 & 0.812 & 1.000 & 0.812 \\
\hline & 0.092 & 0.136 & 0.013 & 15.405 & 0.193 & 0.791 & 1.000 & 0.791 & 0.942 & 1.000 & 0.942 \\
\hline & 0.040 & 0.122 & 0.005 & 16.362 & 0.080 & 0.883 & 1.000 & 0.883 & 0.895 & 0.946 & 0.847 \\
\hline & 0.090 & 0.141 & 0.013 & 13.764 & 0.175 & 0.903 & 1.000 & 0.903 & 0.925 & 0.906 & 0.838 \\
\hline & 0.034 & 0.150 & 0.005 & 14.754 & 0.075 & 0.886 & 1.000 & 0.886 & 1.000 & 1.000 & 1.000 \\
\hline & 0.060 & 0.188 & 0.011 & 13.987 & 0.157 & 0.921 & 1.000 & 0.921 & 1.000 & 1.000 & 1.000 \\
\hline & 0.061 & 0.171 & 0.010 & 14.107 & 0.146 & 1.000 & 1.000 & 1.000 & 1.000 & 1.000 & 1.000 \\
\hline Average & 0.099 & 0.139 & 0.013 & 14.849 & 0.197 & 0.887 & 0.984 & 0.873 & 0.918 & 0.985 & 0.904 \\
\hline \multirow[t]{10}{*}{2} & 0.180 & 0.088 & 0.016 & 13.762 & 0.217 & 0.382 & 0.891 & 0.340 & 0.789 & 1.000 & 0.789 \\
\hline & 0.193 & 0.079 & 0.015 & 14.573 & 0.222 & 0.865 & 1.000 & 0.865 & 0.675 & 1.000 & 0.675 \\
\hline & 0.195 & 0.088 & 0.017 & 13.205 & 0.225 & 1.000 & 1.000 & 1.000 & 0.517 & 1.000 & 0.517 \\
\hline & 0.167 & 0.079 & 0.013 & 14.834 & 0.195 & 0.867 & 0.985 & 0.854 & 0.490 & 1.000 & 0.490 \\
\hline & 0.125 & 0.093 & 0.012 & 16.135 & 0.189 & 0.945 & 1.000 & 0.945 & 0.594 & 1.000 & 0.594 \\
\hline & 0.159 & 0.076 & 0.012 & 16.552 & 0.199 & 0.820 & 0.965 & 0.791 & 0.573 & 1.000 & 0.573 \\
\hline & 0.162 & 0.087 & 0.014 & 14.102 & 0.199 & 0.821 & 1.000 & 0.821 & 0.541 & 1.000 & 0.541 \\
\hline & 0.154 & 0.093 & 0.014 & 14.679 & 0.210 & 0.943 & 1.000 & 0.943 & 0.488 & 1.000 & 0.488 \\
\hline & 0.095 & 0.135 & 0.013 & 17.458 & 0.224 & 0.915 & 1.000 & 0.915 & 0.630 & 1.000 & 0.630 \\
\hline & 0.110 & 0.034 & 0.004 & 19.700 & 0.073 & 0.842 & 1.000 & 0.842 & 0.694 & 0.994 & 0.690 \\
\hline Average & 0.154 & 0.085 & 0.013 & 15.500 & 0.195 & 0.840 & 0.984 & 0.832 & 0.599 & 0.999 & 0.599 \\
\hline \multirow[t]{5}{*}{3} & 0.229 & 0.151 & 0.035 & 5.575 & 0.193 & 0.994 & 1.000 & 0.994 & 0.760 & 0.960 & 0.730 \\
\hline & 0.205 & 0.109 & 0.022 & 6.649 & 0.149 & 0.966 & 0.999 & 0.965 & 0.589 & 0.530 & 0.312 \\
\hline & 0.186 & 0.105 & 0.020 & 6.179 & 0.121 & 0.956 & 0.991 & 0.947 & 0.538 & 0.811 & 0.436 \\
\hline & -0.746 & 0.106 & -0.079 & 5.418 & -0.427 & 0.841 & 0.949 & 0.798 & 0.772 & 0.683 & 0.527 \\
\hline & -0.193 & 0.142 & -0.027 & 13.501 & -0.371 & 0.651 & 0.797 & 0.519 & 0.958 & 0.987 & 0.946 \\
\hline
\end{tabular}


THE INFLUENCE OF EFFICIENCY ESTIMATES ON THE FINANCIAL RATIOS OF SOUTH AFRICAN LISTED BANKS

\begin{tabular}{|c|c|c|c|c|c|c|c|c|c|c|c|}
\hline & PM & $\begin{array}{l}\text { Income/ } \\
\text { Assets }\end{array}$ & ROA & $\begin{array}{l}\text { Asset/ } \\
\text { Equity }\end{array}$ & ROE & TE & $A \varepsilon$ & $C \varepsilon$ & TE & $A \varepsilon$ & $C \varepsilon$ \\
\hline & -0.608 & 0.363 & -0.221 & 11.775 & -2.599 & 0.939 & 1.000 & 0.939 & 1.000 & 1.000 & 1.000 \\
\hline & -0.142 & 0.161 & -0.023 & 7.185 & -0.164 & 1.000 & 1.000 & 1.000 & 1.000 & 0.349 & 0.349 \\
\hline & -0.326 & 0.167 & -0.054 & 6.877 & -0.374 & 1.000 & 0.968 & 0.968 & 0.971 & 0.393 & 0.382 \\
\hline & 0.097 & 0.193 & 0.019 & 4.680 & 0.087 & 1.000 & 1.000 & 1.000 & 1.000 & 0.405 & 0.405 \\
\hline & 0.012 & 0.247 & 0.003 & 8.878 & 0.027 & 1.000 & 1.000 & 1.000 & 1.000 & 0.339 & 0.339 \\
\hline Average & -0.129 & 0.175 & -0.031 & 7.672 & -0.336 & 0.935 & 0.970 & 0.913 & 0.859 & 0.646 & 0.543 \\
\hline \multirow[t]{10}{*}{4} & 0.127 & 0.104 & 0.013 & 13.776 & 0.182 & 0.982 & 1.000 & 0.982 & 0.779 & 1.000 & 0.779 \\
\hline & 0.132 & 0.089 & 0.012 & 13.784 & 0.161 & 1.000 & 1.000 & 1.000 & 0.684 & 0.839 & 0.574 \\
\hline & 0.134 & 0.089 & 0.012 & 13.021 & 0.155 & 0.933 & 0.983 & 0.917 & 0.752 & 0.751 & 0.565 \\
\hline & 0.039 & 0.095 & 0.004 & 14.721 & 0.054 & 1.000 & 1.000 & 1.000 & 0.875 & 0.838 & 0.733 \\
\hline & -0.043 & 0.126 & -0.005 & 17.929 & -0.096 & 0.957 & 1.000 & 0.957 & 0.873 & 0.890 & 0.777 \\
\hline & 0.038 & 0.113 & 0.004 & 13.196 & 0.057 & 0.843 & 1.000 & 0.843 & 1.000 & 1.000 & 1.000 \\
\hline & 0.000 & 0.109 & 0.000 & 0.129 & 0.000 & 0.722 & 1.000 & 0.722 & 0.932 & 0.875 & 0.816 \\
\hline & 0.338 & 0.117 & 0.040 & 9.502 & 0.376 & 0.774 & 1.000 & 0.774 & 0.796 & 0.896 & 0.713 \\
\hline & 0.050 & 0.146 & 0.007 & 9.441 & 0.069 & 0.807 & 1.000 & 0.807 & 0.888 & 0.948 & 0.842 \\
\hline & 0.094 & 0.199 & 0.019 & 12.748 & 0.239 & 0.986 & 0.989 & 0.975 & 0.931 & 0.991 & 0.923 \\
\hline Average & 0.091 & 0.119 & 0.011 & 11.825 & 0.120 & 0.900 & 0.997 & 0.898 & 0.851 & 0.903 & 0.772 \\
\hline \multirow[t]{10}{*}{5} & 0.188 & 0.077 & 0.014 & 17.159 & 0.248 & 0.838 & 0.944 & 0.791 & 0.656 & 1.000 & 0.656 \\
\hline & 0.166 & 0.072 & 0.012 & 17.488 & 0.208 & 0.786 & 0.990 & 0.778 & 0.556 & 0.916 & 0.509 \\
\hline & 0.166 & 0.073 & 0.012 & 18.720 & 0.225 & 0.826 & 0.984 & 0.813 & 0.513 & 1.000 & 0.513 \\
\hline & 0.196 & 0.075 & 0.015 & 15.794 & 0.230 & 0.888 & 0.994 & 0.883 & 0.518 & 1.000 & 0.518 \\
\hline & 0.160 & 0.084 & 0.013 & 15.371 & 0.207 & 0.895 & 1.000 & 0.895 & 0.499 & 1.000 & 0.499 \\
\hline & 0.133 & 0.111 & 0.015 & 11.951 & 0.176 & 0.943 & 1.000 & 0.943 & 0.750 & 0.755 & 0.566 \\
\hline & 0.159 & 0.086 & 0.014 & 12.880 & 0.176 & 0.971 & 1.000 & 0.971 & 0.892 & 0.713 & 0.636 \\
\hline & 0.168 & 0.088 & 0.015 & 12.954 & 0.191 & 0.981 & 1.000 & 0.981 & 0.946 & 0.934 & 0.884 \\
\hline & 0.064 & 0.113 & 0.007 & 12.456 & 0.090 & 1.000 & 0.996 & 0.996 & 0.913 & 1.000 & 0.913 \\
\hline & 0.071 & 0.156 & 0.011 & 11.630 & 0.128 & 1.000 & 1.000 & 1.000 & 1.000 & 1.000 & 1.000 \\
\hline Average & 0.147 & 0.093 & 0.013 & 14.640 & 0.188 & 0.913 & 0.991 & 0.905 & 0.724 & 0.932 & 0.669 \\
\hline Tot. avg. & 0.073 & 0.122 & 0.004 & 12.897 & 0.073 & 0.895 & 0.985 & 0.884 & 0.790 & 0.893 & 0.697 \\
\hline
\end{tabular}

Source: McGregor database and authors' own calculations

\subsection{Financial ratio analysis results}

TABLE 1 also presents the results of the financial ratios in the Du Pont analysis. It seems that 
Bank 1 and Bank 2 are the most profitable. Bank 2 is the most profitable according to the PM ratio with an average of $15.4 \%$, while Bank 1 is the most profitable according to the ROE ratio with an average of $19.7 \%$, and the ROA ratio of Banks 1,2 and 5 are the same with an average of $1.3 \%$. Bank 3 is the most efficient with regard to asset utilisation with an income-to-asset ratio of $17.5 \%$. The average for all the banks together is $12.2 \%$. Bank 2 is the most highly geared, with an asset to equity ratio of 15.5 .

\subsection{Relationship between financial ratio analysis and DEA estimates}

TABLE 2 presents the Spearman's correlation co-efficient $(r)$ between the income statementbased DEA estimates (Model 1 ) and the financial ratio analysis. The $\rho$-value, to test the nullhypothesis, is also given. The null-hypothesis will be rejected at a significance level of $1 \%, 5 \%$ and $10 \%$ respectively if $\rho<\alpha=0.01,=0.05$ and $=0.1$ respectively (two-tailed). It is important to note that all nine times where a significant relationship exists between the DEA estimates and the three profit performance measures (PM, ROA and ROE), i.e. where the null-hypothesis is rejected, the correlation is negative, with is opposite to the expectation in the conceptual framework. There are four significant relationships between the DEA estimates and the financial ratio of income/assets. The correlation is positive, as expected in the conceptual framework. There are seven significant relationships between the DEA estimates and the financial ratio assets/equity, where five show a negative correlation and two a positive correlation. For all the banks together, the relationship between the DEA efficiency estimates and the financial ratios is significant in five instances. The implication of these relationships of the individual banks is indicated in the discussion.

TABLE 2: Correlation coefficient $(r)$ between DEA estimates in Model 1 and financial ratio analysis, and testing of the hypothesis $(\rho)$

\begin{tabular}{|c|c|c|c|c|c|c|c|}
\hline Bank & Efficiency & Model 1 & $P M$ & $R O A$ & ROE & $\begin{array}{l}\text { Incomel } \\
\text { assets }\end{array}$ & $\begin{array}{l}\text { Asset// } \\
\text { equity }\end{array}$ \\
\hline \multirow[t]{6}{*}{1} & Technical & $r$ & -0.102 & -0.051 & -0.140 & 0.140 & -0.702 \\
\hline & & $\rho$ & 0.757 & 0.881 & 0.674 & 0.675 & ${ }^{2} 0.035$ \\
\hline & Allocative & $r$ & -0.683 & -0.683 & -0.751 & 0.068 & -0.444 \\
\hline & & $\rho$ & ${ }^{2} 0.040$ & ${ }^{2} 0.040$ & ${ }^{2} 0.024$ & 0.841 & 0.184 \\
\hline & Cost & $r$ & -0.357 & -0.306 & -0.434 & 0.243 & -0.740 \\
\hline & & $\rho$ & 0.285 & 0.358 & 0.194 & 0.465 & ${ }^{2} 0.026$ \\
\hline \multirow[t]{6}{*}{2} & Technical & $r$ & -0.067 & 0.079 & 0.224 & 0.503 & -0.042 \\
\hline & & $\rho$ & 0.842 & 0.810 & 0.503 & 0.131 & 0.897 \\
\hline & Allocative & $r$ & -0.273 & -0.171 & 0.034 & 0.137 & 0.171 \\
\hline & & $\rho$ & ${ }^{2} 0.040$ & 0.610 & 0.920 & 0.682 & 0.610 \\
\hline & Cost & $r$ & -0.042 & 0.115 & 0.285 & 0.491 & -0.067 \\
\hline & & $\rho$ & 0.897 & 0.726 & 0.395 & 0.142 & 0.841 \\
\hline 3 & Technical & $r$ & 0.426 & 0.410 & 0.410 & 0.442 & -0.249 \\
\hline
\end{tabular}




\begin{tabular}{|c|c|c|c|c|c|c|c|}
\hline Bank & Efficiency & Model 1 & $P M$ & $R O A$ & ROE & $\begin{array}{l}\text { Income/ } \\
\text { assets }\end{array}$ & $\begin{array}{l}\text { Asset// } \\
\text { equity }\end{array}$ \\
\hline & & $\rho$ & 0.201 & 0.219 & 0.219 & 0.184 & 0.453 \\
\hline & Allocative & $r$ & 0.473 & 0.396 & 0.396 & 0.550 & -0.126 \\
\hline & & $\rho$ & 0.156 & 0.234 & 0.234 & ${ }^{3} 0.099$ & 0.704 \\
\hline & Cost & $r$ & 0.491 & 0.477 & 0.477 & 0.449 & -0.267 \\
\hline & & $\rho$ & 0.142 & 0.153 & 0.153 & 0.177 & 0.430 \\
\hline \multirow[t]{6}{*}{4} & Technical & $r$ & 0.102 & 0.077 & 0.128 & -0.319 & 0.753 \\
\hline & & $\rho$ & 0.757 & 0.818 & 0.704 & 0.337 & ${ }^{2} 0.024$ \\
\hline & Allocative & $r$ & -0.408 & -0.353 & -0.245 & 0.136 & 0.136 \\
\hline & & $\rho$ & 0.222 & 0.289 & 0.465 & 0.682 & 0.682 \\
\hline & Cost & $r$ & 0.115 & 0.064 & 0.115 & -0.396 & 0.791 \\
\hline & & $\rho$ & 0.734 & 0.849 & 0.734 & 0.234 & ${ }^{2} 0.018$ \\
\hline \multirow[t]{6}{*}{5} & Technical & $r$ & -0.577 & -0.064 & -0.842 & 0.945 & -0.893 \\
\hline & & $\rho$ & ${ }^{3} 0.084$ & 0.849 & ${ }^{2} 0.011$ & ${ }^{1} 0.005$ & ${ }^{1} 0.007$ \\
\hline & Allocative & $r$ & -0.528 & 0.106 & -0.763 & 0.705 & -0.801 \\
\hline & & $\rho$ & 0.114 & 0.749 & ${ }^{2} 0.022$ & ${ }^{2} 0.035$ & ${ }^{2} 0.016$ \\
\hline & Cost & $r$ & -0.626 & -0.139 & -0.867 & 0.927 & -0.879 \\
\hline & & $\rho$ & ${ }^{2} 0.060$ & 0.674 & ${ }^{1} 0.009$ & ${ }^{1} 0.005$ & ${ }^{1} 0.008$ \\
\hline \multirow[t]{6}{*}{ Total } & Technical & $r$ & -0.103 & 0.014 & -0.214 & 0.280 & -0.332 \\
\hline & & $\rho$ & 0.472 & 0.920 & 0.134 & ${ }^{2} 0.050$ & ${ }^{2} 0.020$ \\
\hline & Allocative & $r$ & -0.096 & -0.076 & -0.224 & 0.128 & -0.150 \\
\hline & & $\rho$ & 0.503 & 0.596 & 0.116 & 0.373 & 0.294 \\
\hline & Cost & $r$ & -0.108 & 0.000 & -0.236 & 0.275 & -0.340 \\
\hline & & $\rho$ & 0.447 & 0.999 & ${ }^{3} 0.099$ & ${ }^{3} 0.054$ & ${ }^{2} 0.017$ \\
\hline
\end{tabular}

${ }^{1}$ Significant at a $99 \%$ confidence level

${ }^{2}$ Significant at a $95 \%$ confidence level

${ }^{3}$ Significant at a $90 \%$ confidence level

\section{Source: Authors'own calculations}

TABLE 3 presents the Spearman's correlation coefficient $(r)$ between the balanced sheet-based DEA estimates (Model 2) and the financial ratio analysis, as well as the $\rho$-value to test the nullhypothesis. It is again important to note that in the eight instances in which a significant relationship exists between the DEA estimates and the three profit performance measures (PM, ROA and ROE), the correlation is negative, the same as in Model 1. The relationship between the $D E A$ estimates and the financial ratio income/assets is significant in eight instances, and, as expected, a positive correlation exists. The relationship between the DEA estimates and the financial ratio assets/equity is significant twice, and both are negatively correlated. For all the 
banks together, the relationships are significant in ten cases, twice as many as in the case of Model l. Again, the implication of these relationships is indicated in the discussion.

TABLE 3: Correlation coefficient $(r)$ between DEA estimates in Model 2 and financial ratio analysis, and testing of the hypothesis $(\rho)$

\begin{tabular}{|c|c|c|c|c|c|c|c|}
\hline Bank & Efficiency & Model 2 & $P M$ & $R O A$ & $R O E$ & $\begin{array}{c}\text { Incomel } \\
\text { Assets }\end{array}$ & $\begin{array}{l}\text { Asset/ } \\
\text { Equity }\end{array}$ \\
\hline \multirow[t]{6}{*}{1} & Technical & $r$ & -0.715 & -0.687 & -0.701 & 0.786 & -0.351 \\
\hline & & $\rho$ & ${ }^{2} 0.032$ & ${ }^{2} 0.039$ & ${ }^{2} 0.036$ & ${ }^{2} 0.018$ & 0.294 \\
\hline & Allocative & $r$ & 0.245 & 0.190 & 0.245 & 0.027 & 0.245 \\
\hline & & $\rho$ & 0.465 & 0.569 & 0.465 & 0.936 & 0.465 \\
\hline & Cost & $r$ & -0.295 & -0.295 & -0.281 & 0.645 & -0.154 \\
\hline & & $\rho$ & 0.379 & 0.379 & 0.401 & ${ }^{2} 0.052$ & 0.646 \\
\hline \multirow[t]{6}{*}{2} & Technical & $r$ & -0.127 & -0.164 & -0.030 & -0.139 & 0.200 \\
\hline & & $\rho$ & 0.704 & 0.624 & 0.928 & 0.674 & 0.549 \\
\hline & Allocative & $r$ & 0.406 & 0.522 & 0.522 & 0.522 & -0.522 \\
\hline & & $\rho$ & 0.465 & 0.116 & 0.116 & 0.116 & 0.116 \\
\hline & Cost & $r$ & -0.127 & -0.164 & -0.030 & -0.139 & 0.200 \\
\hline & & $\rho$ & 0.704 & 0.624 & 0.928 & 0.674 & 0.549 \\
\hline \multirow[t]{6}{*}{3} & Technical & $r$ & -0.506 & -0.555 & -0.555 & 0.860 & 0.362 \\
\hline & & $\rho$ & 0.129 & ${ }^{3} 0.095$ & ${ }^{3} 0.097$ & ${ }^{1} 0.010$ & 0.276 \\
\hline & Allocative & $r$ & -0.079 & -0.127 & -0.127 & -0.224 & 0.127 \\
\hline & & $\rho$ & 0.810 & 0.704 & 0.704 & 0.503 & 0.704 \\
\hline & Cost & $r$ & -0.345 & -0.382 & -0.382 & 0.006 & 0.127 \\
\hline & & $\rho$ & 0.298 & 0.250 & 0.250 & 0.984 & 0.704 \\
\hline \multirow[t]{6}{*}{4} & Technical & $r$ & -0.673 & -0.370 & -0.382 & 0.588 & -0.394 \\
\hline & & $\rho$ & ${ }^{2} 0.043$ & 0.267 & 0.250 & ${ }^{3} 0.078$ & 0.238 \\
\hline & Allocative & $r$ & -0.128 & 0.281 & 0.306 & 0.625 & -0.191 \\
\hline & & $\rho$ & 0.704 & 0.401 & 0.358 & ${ }^{3} 0.060$ & 0.569 \\
\hline & Cost & $r$ & -0.564 & -0.164 & -0.152 & 0.673 & -0.309 \\
\hline & & $\rho$ & ${ }^{3} 0.091$ & 0.624 & 0.653 & ${ }^{2} 0.043$ & 0.352 \\
\hline \multirow[t]{4}{*}{5} & Technical & $r$ & -0.430 & -0.055 & -0.697 & 0.782 & -0.733 \\
\hline & & $\rho$ & 0.197 & 0.873 & ${ }^{2} 0.018$ & ${ }^{2} 0.019$ & ${ }^{2} 0.028$ \\
\hline & Allocative & $r$ & 0.224 & -0.295 & 0.295 & -0.049 & 0.246 \\
\hline & & $\rho$ & 0.503 & 0.379 & 0.379 & 0.881 & 0.465 \\
\hline
\end{tabular}




\begin{tabular}{cccccccc}
\hline Bank & Efficiency & Model2 & $P M$ & ROA & ROE & $\begin{array}{c}\text { Income/ } \\
\text { Assets }\end{array}$ & $\begin{array}{c}\text { Asset/ } \\
\text { Equity }\end{array}$ \\
\hline \multirow{3}{*}{ Total } & Cost & $r$ & -0.332 & -0.103 & -0.552 & 0.770 & -0.648 \\
& & $\rho$ & 0.322 & 0.757 & 0.097 & ${ }^{1} 0.010$ & ${ }^{3} 0.051$ \\
& \multirow{3}{*}{ Technical } & $r$ & -0.671 & -0.410 & -0.520 & 0.767 & -0.392 \\
& & $\rho$ & ${ }^{1} 0.000$ & ${ }^{1} 0.004$ & ${ }^{1} 0.000$ & ${ }^{1} 0.000$ & ${ }^{1} 0.006$ \\
& Allocative & $r$ & 0.238 & 0.180 & 0.509 & -0.222 & 0.582 \\
& & $\rho$ & ${ }^{3} 0.095$ & 0.208 & 10.000 & 0.121 & ${ }^{1} 0.000$ \\
& \multirow{2}{*}{ Cost } & $r$ & -0.307 & -0.146 & -0.036 & 0.368 & 0.101 \\
& & $\rho$ & ${ }^{2} 0.032$ & 0.308 & 0.803 & 10.010 & 0.478 \\
\hline
\end{tabular}

${ }^{1}$ Significant at a $99 \%$ confidence level

${ }^{2}$ Significant at a $95 \%$ confidence level

${ }^{3}$ Significant at a $90 \%$ confidence level

Source: Authors'own calculations

\section{DISCUSSION}

The following discussion refers to the cases where a significant relationship between the efficiencies and financial ratios was found. This is also an attempt to answer the research question, which is broken into the four parts as indicated in the conceptual framework.

\subsection{Model 1 and the financial ratios}

\subsubsection{Technical efficiency}

This part comments on how the input-output ratio of deposits and staff and operating costs to the interest and non-interest income of a bank influences its profitability, its efficiency in utilising assets to generate income and its capital structure. An improvement in technical efficiency will lead to the following: for Bank 5 , it means a decrease in its profitability as measured by PM and ROE, but an increase in its efficiency in utilising assets to generate income. For Bank 1 and Bank 5, it means a lower-geared capital structure, while it means a highergeared capital structure for Bank 4. For all the banks together, it will result in an increase in the efficiency in utilising assets to generate income, and a lower-geared capital structure.

\subsubsection{Allocative efficiency}

This part comments on how the input-mix ratio of deposits and staff and operating costs to generate the interest income and non-interest income of a bank influence its profitability, its efficiency in utilising assets to generate income and its capital structure. An improvement in allocative efficiency will lead to the following: a decrease in the profitability for Bank 1 and Bank 5, as measured by PM, a decrease in the profitability of Bank 1 , as measured by ROA, and a decrease in the profitability of Bank 1 and Bank 5 , as measured by ROE. The efficiency in utilising assets to generate income will also increase for Bank 3 and Bank 5. 


\subsection{Model 2 and the financial ratios}

\subsubsection{Technical efficiency}

This part comments on how the input-output ratio of fixed assets and financial capital to the deposits and loans of a bank influences its profitability, its efficiency in utilising assets to generate income and its capital structure. An improvement in the technical efficiency will lead to the following: a decrease in the profitability of Bank 1, as measured by PM, ROA and ROE, Bank 3 , as measured by ROA and ROE, Bank 4, as measured by PM and Bank 5, as measured by ROE; and an increase in the efficiency in utilising assets to generate income for Banks 1, 3, 4 and 5. It also means a lower-geared capital structure for Bank 5. For all the banks together, all the profitability ratios will decrease, as measured by PM, ROA and ROE, the efficiency in utilising assets to generate income will increase, and the capital structure will be lower-geared.

\subsubsection{Allocative efficiency}

This part comments on how the input-mix ratio of financial capital and fixed assets to generate the deposits and loans of a bank influences its profitability, its efficiency in utilising assets to generate income and its capital structure. An improvement in the allocative efficiency will lead to the following: an increase for Bank 4 in the utilisation of assets to generate income. For all the banks together, it means an increase in the profitability as measured by PM and ROE, and also a higher-geared capital structure.

\section{CONCLUSION}

This study investigated the performance of five listed banks on the JSE Limited over a ten-year period. It did this firstly by using two DEA models (one mainly income statement-based and the other balance sheet-based), and secondly by using the financial ratios included in the Du Pont analysis.

Cost efficiency is an aggregation of technical and allocative efficiency. In order to offer a more detailed analysis of the data, the findings and discussion were mainly focused on technical and allocative efficiency. The most important finding is that where significant relationships exist, the technical efficiency (of both income statement-based and balance sheet-based DEA models) of the individual banks and of all of the banks together is in all cases negatively correlated to all three profitability ratios. Under the same circumstances, technical efficiency is in all cases positively correlated to income/assets. The significant relationships between allocative efficiency (both DEA models) and the profitability ratios of individual banks are negatively correlated. With regard to the banks in total, it correlates positively to PM and ROE. As in the case of technical efficiency, allocative efficiency also correlates positively to income/assets.

Given the results, the study concludes that where inputs are financial capital and fixed assets, and outputs are deposits and loans, the more inefficient banks become with regard to their input-output ratio the better they will perform with profit relative to total income, assets and equity. The opposite is true for income/assets, namely an improvement in the input-output efficiency of banks leads to an increase in this ratio. The more efficient banks are with optimal input mixes, the better they will perform with profit relative to income and equity. Where inputs 
are deposits and staff and operating costs, and outputs are interest income and non-interest income, banks that become more efficient in their input-output ratios will also perform better with their income/asset ratio.

The main lesson from this study is that an increase in efficiency will not necessarily result in better performance ratios. There is a very positive correlation between these two measures of performance. These two measures do not use, or intend to use, the same data, and they do not explain, or intend to explain, the same performance. Therefore, the one cannot substitute for the other. As the result of increased competition from foreign banks, local banks should use both methods to evaluate different aspects of performance in order to stay competitive.

Further research should be done to determine why the relationship between the efficiency measures and profitability ratios is negative. Researchers should consider other variables including non-financial data, or other combinations of variables, in their DEA model(s) and/or take time lags into account.

\section{REFERENCES}

Aly, H.Y., Grabowski, R., Pasurka, C. \& Rangan, N. (1990). Technical, scale, and allocative efficiencies in US Banking: An empirical investigation, Review of Economics and Statistics, 72(2), pp. 211218.

Avkiran, N. (1999). An application reference for data envelopment analysis in branch banking: Helping the novice researcher, International Journal of Bank Marketing, 17(5), pp. 206-220.

Berger, A.N. \& Humphrey, D.B. (1997). Efficiency of financial institutions: International survey and directions for further research, European Journal of Operational Research, 98(1), pp. 175-212.

Brigham, E.F. \& Ehrhardt, M.C. (2005). Financial management: Theory and practice. Ohio: Mason.

Charnes, A., Cooper, W.W. \& Rhodes, દ. (1978). Measuring efficiency of decision-making units, European Journal of Operations Research, 2(1), pp. 429-444.

Charnes, A., Cooper, W.W. \& Haung, Z.M. (1990). Polyhedral cone-ratio DEA models with an illustrative application to large commercial banks, Journal of Econometrics, 46(1), pp. 213-227.

Chen, T. (1998). A study of bank efficiency and ownership in Taiwan, Applied Economic Letters, 5(10), pp. 613-617.

Chen, T. (2002). Measuring firm performance with DEA and prior information in Taiwan's banks, Applied Economic Letters, 9(1), pp. 201-204.

Coelli, T. (1996). A Guide to DEAP Version 2.1: A data envelopment analysis (computer)Program. Department of Econometrics, University of New England, Armidale. (CEPA Working Paper 96/07).

Coelli, T.J., Rao, D.S.P., O’Donnell, C.J. \& Battese, G.E. (2005). An introduction to efficiency and productivity analysis. New York: Springer.

Correia, C., Flynn, D., Uliana, E. \& Wormald, M. (2007). Financial management. Cape Town: Juta.

Correia, C., Langfield-Smith, K., Thorne, H. \& Hilton, R. (2008). Management accounting: Information for managers and creating value. Berkshire: McGraw-Hill.

Cronje, J.J.L. (2002). Data envelopment analysis as a measure for technical efficiency measurement in banking - a research framework, Southern African Business Review, 6(2), pp. 32-41. 
Cronje, J.J.L. (2007). Assessing the relative efficiency management of South African banks, Management Dynamics, 16(4), pp. 11-23.

Dempsey, A. \& Pieters, H.N. (2005). Inleiding tot Finansiële Rekeningkunde. Durban: LexisNexis Butterworths.

Devaney, M. \& Weber, W.L. (2000). Productivity growth, market structure, and technological change: Evidence from the rural banking sector, Applied Financial Economics, 10, pp. 587-595.

Drake, L. (2001). Efficiency and productivity change in UK banking, Applied Financial Economics, 11(1), pp. 557-571.

Elyasiani, E. \& Mehdian, S.M. (1992). Productive efficiency performance of minority and non-minority owned banks: A non-parametric approach. Journal of Banking and Finance, 17(1), pp. 349-366.

Favero, C.A. \& Papi, L. (1995). Technical efficiency and scale efficiency in the Italian banking sector: A non-parametric approach, Applied Economics, 27(1), pp. 385-395.

Halkos, G.E. \& Dimitrios, S. (2004). Efficiency measurement of the Greek commercial banks with the use of financial ratios: A data envelopment analysis approach, Management Accounting Research, 15(2), pp. 201-224.

Hanke, E.J., Wichern, D.W. \& Reitsch, A.G. (2001). Business forecasting. Upper Saddle River: PrenticeHall.

Hassan AI-Tamimi, H.A., \& Lootah, A.M. (2007). Evaluating the operational and profitability efficiency of a UAE-based commercial bank, Journal of Financial Services Marketing, 11(4), pp. $333-348$.

Horngren, C.T., Datar, S.M., Foster, G., Rajan, M. \& Ittner, C. (2009). Cost accounting: A managerial emphasis. Upper Saddle River: Pearson / Prentice-Hall.

International Accounting Standards Board (IASB). (2006). IAS 30: Presentation of Financial Statements. London: IASB.

Molyneux, P., Altunbas, Y. \& Gardener, દ. (1996). Efficiency in European banking. Chichester: Wiley.

Millard, S.P. \& Neerchal, H.K. (2001). Environmental statistics with S-plus. Florida: CRC Press.

Oberholzer, M. \& Van der Westhuizen, G. (2004). An empirical study on measuring profitability and efficiency of bank regions, Meditari, 12(1), pp. 165-178.

Oberholzer, M. \& Van der Westhuizen, G. (2009). Estimating technical and scale efficiency in banks and its relationship with economic value added: A South African study, South African Journal of Accounting Research, 23(1), pp. 67-86.

O'Donnell, C.J. \& Van der Westhuizen, G. (2002). Regional comparisons of banking performance in South Africa, The South African Journal of Economics, 70(3), pp. 485-518.

Ray, S.C. (2004). Data envelopment analysis: Theory and techniques for economics and operational research. Cambridge: Cambridge University Press.

Rangan, N., Grabowski, R., Aly, H.Y. \& Pasurka, C. (1988). The technical efficiency of US banks, Economics Letters, 28(1), pp. 169-175.

Sake-Rapport, (2009, February 6). FTSE/JSE Afrika-reeks Indekse, p 8.

Sekaran, U. (2006). Research methods for business: A skill building approach. Singapore: Wiley. 
Sherman, H.D. \& Gold, F. (1985). Bank branch operating efficiency: Evaluation with data envelopment analysis, Journal of Banking and Finance, 9(1), pp. 297-315.

Sherman, H.D. \& Ladino, G. (1995). Managing bank productivity: Using data envelopment analysis (DEA), Interfaces, 25(1), pp. 60-73.

Stavarek, D. (2002). Comparison of the relative efficiency of banks in European transition economies. Proceedings of the D.A. Tsenov Academy of Economics $50^{\text {Th }}$ Anniversary Financial Conference, Svishtov, Bulgaria, April 2002, pp. 955-971.

Thomas, D. \& Tripe, D. (2007). An investigation into the efficiency of a bank's branch network using data envelopment analysis. Available from: http://www.melbournecentre.com.au/Finsia_ MCFC/2007/DavidTripe_1. (Accessed 12 June 2009)

Van der Westhuizen, G. (2008). Estimating technical and scale efficiency and sources of efficiency change in banks using balance sheet data: A South African study, Studies in Economics and Econometrics (SEع), 32(1), pp. 23-45.

Van der Westhuizen, G. \& Oberholzer, M. (2003). A model to compare bank size and the performance of banks by using financial statement analysis and data envelopment analysis, Management Dynamics, 12(4), pp. 18-26.

Vose, D. (1996). Quantitative risk analysis. A guide to Monte Carlo simulation modelling. Chichester: Wiley.

Wheelock, D.C. \& Wilson, P.W. (1995). Evaluating the efficiency of commercial banks: Does our view on what banks do matter? Review, Federal Reserve Bank of St Louis, pp. 39-52.

Yeh, Q. (1996). The application of data envelopment analysis in conjunction with financial ratios for bank performance evaluation, Journal of the Operational Research Society, 47(1), pp. 980-988. 
Oberholzer \& Van der Westhuizen 